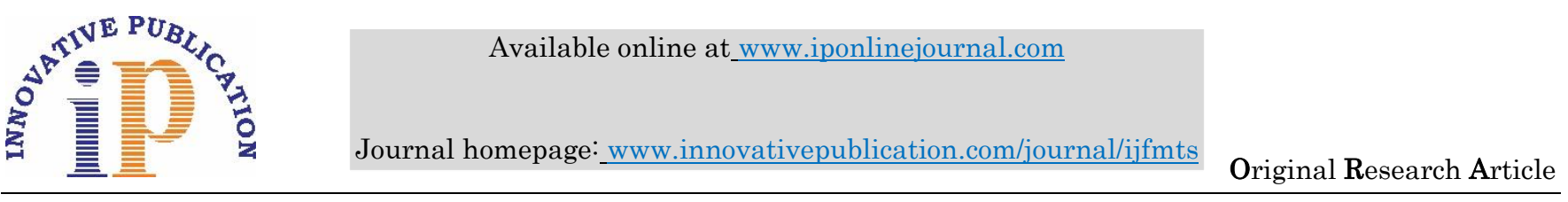

\title{
Forensic analysis of automobile paint of Indian company
}

\author{
Priyanka Verma ${ }^{1 *}$, Manmeet kaur ${ }^{2}$, Navjot Kaur ${ }^{3}$ \\ ${ }^{1}$ Assistant Professor, ${ }^{2}$ Student, ${ }^{3}$ Research Scholar, Dept. of Forensic Science \& Toxicology, ${ }^{\mathbf{1 - 3}}$ Chandigarh University, \\ Gharaun, Mohali Punjab, India
}

\begin{abstract}
The present study was done in an attempt to distinguish between paint samples of automobiles obtained from cars of same company "MARUTI". 20 samples of paint were analyzed with the help of solubility tests and 5 samples with the help of instruments such as UV Spectrophotometry each. The solubility tests were performed using 3 liquids, Chloroform, Sulphuric acid and Nitric acid. The results obtained clearly proved that the combination of both methods yields better results than when used individually. Through this research, a database has been created which can be useful in further forensic related work. It can be really helpful in hit and run cases where possibility of exchange of paint is very high.
\end{abstract}

Keywords: Solubility tests, UV Spectrophotometry, Automobile paint, Forensic analysis.

\section{Introduction}

Paint can be considered phenomenal forensic evidence or evidence that can be helpful to solve crimes. It is a type of trace evidence like glass, hairs and fibers that can be found in trace amounts on the crime scene but can be solely responsible for the conviction of the perpetrator. Automobile paint evidence can be especially relevant in hit and run cases or other cases where automobiles are involved. Car paint is one of the most received evidence in forensic laboratories. The paint chips or paint smears are generally transferred from the car to the clothing of the victim or another car during an impact with the first car. Paint chips and smears can be easily compared to a suspect's vehicle to check whether the vehicle has been involved in any hit and run accident or not. These chips can also be matched by fitting them to any missing section on the vehicle like puzzle pieces are fitted.

Automotive paint is paint which is used for protection and decoration on the automobile. The widely used paint nowadays is water based acrylic polyurethane enamel paint due to its less harmful effect on the environment. ${ }^{1}$ Modern used automobile paint is applied with a thickness of $100 \mu \mathrm{m}(0.1 \mathrm{~mm})$.
Automobile paint consists of mainly three components; binder, pigment and additives.

There are many research articles published on paint evidence nowadays. In most of them, the primarily used method of examination is visual examination using microscopy ${ }^{5,7}$ as in Gothard (1976) and Ryland (1978). Solubility tests and chemical tests were also used as a way of identifying various pigments present in the paint sample as done by Cassissta and Sandercock in 1994. They performed micro chemical spot tests to identify the number and type of pigments present in the paint samples.

For the confirmatory tests, Instrumentation is proven to be the best method used to identify and quantify all the elements present in the paint samples. FTIR was the most favored technique in all the current research papers. ${ }^{25}$ This was due to the fact that it gives accurate results and is easy to use. Usually FTIR was coupled with a number of techniques; Pyrolysis gas chromatography, ${ }^{9,10}$ SEM-EDX, ${ }^{21} \quad$ Raman spectroscopy. ${ }^{24}$ Another technique used was LA-ICP$\mathrm{MS}^{19}$ which was sometimes coupled with FTIR but sometimes used alone. This yielded surprising good results.

\footnotetext{
*Corresponding Author: Priyanka Verma, Dept. of Forensic Science \& Toxicology, Chandigarh University, Gharaun, Mohali Punjab, India Email: priyankakverma25@gmail.com http://doi.org/10.18231/j.ijfmts.2019.017
} 
This study used UV Spectrophotometry and Solubility tests in combination to identify various elements present in the sample. Peaks were obtained which matched certain elements through which they were identified. UV Spectrophotometry proved to be really useful technique to differentiate between different samples of same company by identifying elements that were specifically present in them.

The results obtained from the analysis of paint using instrumentation yielded the results that combination of 2-3 techniques always gives accurate results rather than using single technique. Coupling of techniques is the best way to ensure that all the elements that are present in the sample are identified and quantified.

\section{Materials and Methods}

\section{Collection of Samples}

In this study, 20 samples of paint chips were collected from cars of Indian brand "MARUTI". They were collected from various sources like Police Stations, Denting and Painting shops, Showrooms located in the area of Mohali, Ludhiana and Sri Muktsar Sahib. One company was targeted due to a large number of cars of this brand only. The paint chips were collected using Surgical Blade.

\section{Analysis}

\section{Solubility tests}

Solubility tests were performed using chemicals like Chloroform, Sulphuric Acid and Nitric Acid. The chips were dipped in these chemicals for 3 days. Every day, the test tubes containing the heterogeneous mixture were observed. The changes occurring in them were carefully observed and noted down.

\section{Instrumental analysis}

Instrumental analysis was also done with the help of UV Spectrophotometer. This instrument was chosen because it gives the most accurate result in combination as to which elements are present in the given paint sample. Also the results are precise and provide us with even the smallest element present in the paint sample. UV Spectrophotometer gives results in the form of peaks in the ultraviolet range that is $10 \mathrm{~nm}$ to $400 \mathrm{~nm}$.

\section{Results and Discussion}

In this study, 3 chemicals were used for the purpose of solubility tests; Sulphuric acid, Nitric acid and Chloroform.

With Sulphuric acid, the samples interacted the most. Slight Shrinkage and curling was seen on the very first day. Another important thing was formation of dark brown/ black rings on the surface of solution in which the sample floated whereas rest of the solution was clear. Fragmentation was also seen starting on first day in many samples. By the second day, the rings formed were still intact in many but in some samples, It was replaced by muddy or brown colored liquid in which the samples were either floating or were settled down. Another thing was separation of layers of samples. On the second day, only top layer was seen separated from the sample whereas by the third day, every layer was separated from each other.

Table 1: Showing changes occurred in various samples when dissolved in Sulphuric acid $\left(\mathrm{H}_{2} \mathrm{SO}_{4}\right)$

\begin{tabular}{|c|l|l|l|}
\hline Sample No. & \multicolumn{1}{|c|}{ Day 1 } & \multicolumn{1}{|c|}{ Day 2 Day 3 } \\
\hline 1. & $\begin{array}{l}\text { Shrinkage, Bleeding brown, } \\
\text { Top layer removed which } \\
\text { floated }\end{array}$ & $\begin{array}{l}\text { Dark brown ring formed on } \\
\text { upper side of solution while } \\
\text { rest of the solution is slight } \\
\text { yellow, Fragmented sample }\end{array}$ & $\begin{array}{l}\text { Dark brown colored } \\
\text { solution with sample } \\
\text { floating in it, NOC }\end{array}$ \\
\hline 2. & $\begin{array}{l}\text { Slight shrinkage, Dark } \\
\text { brown ring formed on } \\
\text { upper side of solution while } \\
\text { rest of the solution is clear }\end{array}$ & $\begin{array}{l}\text { Floating sample, Complete } \\
\text { shrinkage of sample }\end{array}$ & $\begin{array}{l}\text { Dark brown colored } \\
\text { solution, NOC }\end{array}$ \\
\hline 3. & Bleeding light yellow, & Urine colored solution & NOC \\
\hline
\end{tabular}




\begin{tabular}{|c|c|c|c|}
\hline & Floating, Slightly shrinked & & \\
\hline 4. & $\begin{array}{l}\text { Sample gets enlarged, Dark } \\
\text { brown ring formed on } \\
\text { upper side of solution while } \\
\text { rest of the solution is clear }\end{array}$ & $\begin{array}{l}\text { Sample floating, papery, soft } \\
\text { and curled, Muddy colored } \\
\text { and dense solution }\end{array}$ & $\begin{array}{l}\text { Layers of sample gets } \\
\text { separated, NOC }\end{array}$ \\
\hline 5. & $\begin{array}{l}\text { Bleeding light brown, Dark } \\
\text { brown ring formed on } \\
\text { upper side of solution while } \\
\text { rest of the solution is clear }\end{array}$ & $\begin{array}{l}\text { Dark brown ring formed on } \\
\text { upper side of solution while } \\
\text { rest of the solution is slight } \\
\text { yellow, Fragmented sample }\end{array}$ & $\begin{array}{l}\text { Ring remain intact with } \\
\text { pieces of sample floating } \\
\text { in it }\end{array}$ \\
\hline 6. & $\begin{array}{l}\text { Dark brown ring formed on } \\
\text { upper side of solution while } \\
\text { rest of the solution is slight } \\
\text { yellow, Fragmented sample }\end{array}$ & $\begin{array}{l}\text { Ring intact with sample } \\
\text { floating in it. }\end{array}$ & NOC \\
\hline 7. & $\begin{array}{l}\text { Slightly curled, Top layers } \\
\text { gets separated and starts } \\
\text { floating }\end{array}$ & $\begin{array}{l}\text { Sample became soft and } \\
\text { papery, Solution becomes } \\
\text { dark brown }\end{array}$ & $\begin{array}{l}\text { All the layers gets } \\
\text { separated, NOC }\end{array}$ \\
\hline 8. & $\begin{array}{l}\text { Fragmentation begins, } \\
\text { Dense liquid }\end{array}$ & $\begin{array}{l}\text { Muddy colored dense } \\
\text { solution, Sample curled and } \\
\text { floating }\end{array}$ & $\begin{array}{l}\text { Fragmentation completes, } \\
\text { Slightly curled fragments }\end{array}$ \\
\hline 9. & $\begin{array}{l}\text { Shrinkage, Bleeding brown, } \\
\text { Top layer removed which } \\
\text { floated }\end{array}$ & $\begin{array}{l}\text { Sample floating, papery, soft } \\
\text { and curled, Muddy colored } \\
\text { and dense solution }\end{array}$ & NOC \\
\hline 10. & $\begin{array}{l}\text { Black colored solution with } \\
\text { sample floating in it, } \\
\text { Sample slightly curled, } \\
\text { Floating }\end{array}$ & $\begin{array}{l}\text { Black colored ring with } \\
\text { fragments of sample formed } \\
\text { on upper side while rest of the } \\
\text { solution is yellow }\end{array}$ & $\begin{array}{l}\text { Sinking of sample, black } \\
\text { ring remain intact }\end{array}$ \\
\hline 11. & $\begin{array}{l}\text { Fragmentation } \\
\text { Brown colored solution, } \\
\text { Dense liquid }\end{array}$ & $\begin{array}{l}\text { Sample became soft and } \\
\text { papery, Dark brown color } \\
\text { occurred }\end{array}$ & $\begin{array}{l}\text { Complete fragmentation } \\
\text { of sample, NOC }\end{array}$ \\
\hline 12. & $\begin{array}{l}\text { Fragmentation } \quad \text { begins, } \\
\text { Floating sample }\end{array}$ & Black colored solution & $\begin{array}{l}\text { Sample almost dissolved } \\
\text { and visible only when } \\
\text { shaked }\end{array}$ \\
\hline 13. & $\begin{array}{l}\text { Fragmentation begins, } \\
\text { Dense liquid }\end{array}$ & $\begin{array}{l}\text { Muddy colored dense } \\
\text { solution, Sample curled and } \\
\text { floating }\end{array}$ & $\begin{array}{l}\text { Fragmentation completes, } \\
\text { Slightly curled fragments }\end{array}$ \\
\hline 14. & Bleeding light yellow & $\mathrm{NOC}$ & $\mathrm{NOC}$ \\
\hline 15. & $\begin{array}{l}\text { Slight shrinkage, Dark } \\
\text { brown ring formed on } \\
\text { upper side of solution while } \\
\text { rest of the solution is clear }\end{array}$ & $\begin{array}{l}\text { Ring intact with sample } \\
\text { floating in it }\end{array}$ & $\begin{array}{l}\text { Dark brown colored } \\
\text { solution, NOC }\end{array}$ \\
\hline 16. & $\begin{array}{l}\text { Slightly curled, Dark brown } \\
\text { ring formed on upper side } \\
\text { of solution which contains } \\
\text { sample, while rest of the } \\
\text { solution is clear }\end{array}$ & $\begin{array}{l}\text { Fragmented sample, Dense } \\
\text { muddy colored solution with } \\
\text { fragments floating in it }\end{array}$ & NOC \\
\hline
\end{tabular}




\begin{tabular}{|c|l|l|l|}
\hline 17. & $\begin{array}{l}\text { Fragmentation begins, } \\
\text { Dense brown colored liquid }\end{array}$ & $\begin{array}{l}\text { Muddy colored dense } \\
\text { solution, Sample curled and } \\
\text { floating }\end{array}$ & $\begin{array}{l}\text { Fragmentation completes, } \\
\text { Slightly curled fragments }\end{array}$ \\
\hline 18. & $\begin{array}{l}\text { Slight shrinkage, Dark } \\
\text { brown ring formed on } \\
\text { upper side of solution while } \\
\text { rest of the solution is clear }\end{array}$ & $\begin{array}{l}\text { Floating sample, Complete } \\
\text { shrinkage of sample }\end{array}$ & $\begin{array}{l}\text { Dark brown colored } \\
\text { solution, NOC }\end{array}$ \\
\hline 19. & $\begin{array}{l}\text { Slightly curled, Top layers } \\
\text { gets separated and starts } \\
\text { floating }\end{array}$ & $\begin{array}{l}\text { Sample became soft and } \\
\text { papery, Solution becomes } \\
\text { dark brown }\end{array}$ & $\begin{array}{l}\text { All the layers gets } \\
\text { separated, NOC }\end{array}$ \\
\hline 20. & $\begin{array}{l}\text { Bleeding light yellow, } \\
\text { sample floating and slightly } \\
\text { curled }\end{array}$ & Urine colored solution & NOC \\
\hline
\end{tabular}

In Nitric acid, the samples reacted mildly. The samples either slightly curled or shrank on the first day. Some of the samples even got swollen. Slight fragmentation was also seen. The second day was when most of the bleeding occurred. Most samples bleeded yellow / urine color whereas 2-3 were seen bleeding light green color. Fragmentation was seen reaching its peaks. Curling and shrinking of the samples was also seen. By the third day, most of the samples did not show any further changes but some samples bleeded yellow. An interesting thing to note was that this was the only liquid in which some samples do not reacted at all on any day.

Table 2: Showing changes occurred in various samples when dissolved in Nitric acid $\left(\mathrm{HNO}_{3}\right)$

\begin{tabular}{|c|c|c|c|}
\hline Sample No. & Day 1 & Day 2 & Day 3 \\
\hline 1. & $\begin{array}{l}\text { Slight color change to light } \\
\text { yellow }\end{array}$ & $\begin{array}{l}\text { Urine colored solution, } \\
\text { Sample shrank and sank }\end{array}$ & $\mathrm{NOC}$ \\
\hline 2. & $\begin{array}{l}\text { Fragmentation starts and } \\
\text { slight bleeding }\end{array}$ & $\begin{array}{l}\text { Urine colored solution, } \\
\text { Fragmentation complete }\end{array}$ & $\mathrm{NOC}$ \\
\hline 3. & No visible changes & No visible changes & No visible changes \\
\hline 4. & $\begin{array}{l}\text { Slightly curled, Settled } \\
\text { down, Shrinking done }\end{array}$ & $\begin{array}{l}\text { Sample curled and solution is } \\
\text { cloudy in nature }\end{array}$ & $\begin{array}{l}\text { Sample fragmented into } \\
\text { large pieces }\end{array}$ \\
\hline 5. & $\begin{array}{l}\text { Curled, bleeding slight } \\
\text { yellow, Fragmentation and } \\
\text { shrinking starts }\end{array}$ & $\begin{array}{l}\text { Sample curled, fragmented } \\
\text { and settled down }\end{array}$ & NOC \\
\hline 6. & $\begin{array}{l}\text { Sample curled, float, and } \\
\text { bleed white }\end{array}$ & Sample settled down & No other visible changes \\
\hline 7. & $\begin{array}{l}\text { Sample curled and swollen, } \\
\text { Top layer gets separated }\end{array}$ & $\begin{array}{l}\text { Top layer fragmented while } \\
\text { other layers still intact, } \\
\text { Sample swollen and bleeds } \\
\text { light yellow }\end{array}$ & $\begin{array}{l}\text { Sample floats and starting } \\
\text { to get fragmented into } \\
\text { further very little pieces }\end{array}$ \\
\hline 8. & $\begin{array}{l}\text { Slight color change to light } \\
\text { yellow }\end{array}$ & Fragmentation starts & $\begin{array}{l}\text { Fragmentation completes, } \\
\text { NOC }\end{array}$ \\
\hline 9. & $\begin{array}{l}\text { Sample curled, float, and } \\
\text { bleed white }\end{array}$ & Sample settled down & $\mathrm{NOC}$ \\
\hline 10. & $\begin{array}{lr}\text { Bleeding slight } & \text { yellow, } \\
\text { Fragmentation } & \text { and } \\
\end{array}$ & $\begin{array}{l}\text { Sample curled, fragmented } \\
\text { and swollen, Bleeds light }\end{array}$ & $\begin{array}{l}\text { Some of the sample float } \\
\text { and some sank }\end{array}$ \\
\hline
\end{tabular}




\begin{tabular}{|c|c|c|c|}
\hline & shrinking starts & green color & \\
\hline 11. & $\begin{array}{l}\text { Swollen and curled sample, } \\
\text { Top layer gets separated } \\
\text { and floats }\end{array}$ & $\begin{array}{l}\text { All the layers gets separated, } \\
\text { Fragmentation starts, yellow } \\
\text { colored solution }\end{array}$ & $\begin{array}{l}\text { Sample settled down, } \\
\text { NOC }\end{array}$ \\
\hline 12. & $\begin{array}{l}\text { Sample gets swelled and } \\
\text { floats, Fragmentation starts }\end{array}$ & $\begin{array}{lcr}\text { Sample } & \text { swollen } & \text { and } \\
\text { fragmented, } & \text { Bleeds } & \text { light } \\
\text { green } & & \end{array}$ & $\begin{array}{l}\text { Sample settled down, } \\
\text { NOC }\end{array}$ \\
\hline 13. & $\begin{array}{l}\text { Sample curled and swollen, } \\
\text { Top layer gets separated }\end{array}$ & $\begin{array}{l}\text { All the sample gets } \\
\text { fragmented }\end{array}$ & Bleed slight yellow \\
\hline 14. & $\begin{array}{lr}\text { Bleeding slight } & \text { yellow, } \\
\text { Fragmentation } & \text { and } \\
\text { shrinking starts } & \end{array}$ & $\begin{array}{l}\text { Sample curled, fragmented } \\
\text { and swollen, Bleeds light } \\
\text { green color }\end{array}$ & $\begin{array}{l}\text { Some of the sample float } \\
\text { and some sank }\end{array}$ \\
\hline 15. & $\begin{array}{l}\text { Sample curled and solution } \\
\text { is cloudy in nature }\end{array}$ & $\begin{array}{l}\text { Sample fragmented into large } \\
\text { pieces }\end{array}$ & NOC \\
\hline 16. & $\begin{array}{l}\text { Sample curled, float, and } \\
\text { bleed white }\end{array}$ & Sample settled down & No other visible changes \\
\hline 17. & $\begin{array}{l}\text { Solution slight yellow and } \\
\text { opaque in nature }\end{array}$ & $\begin{array}{l}\text { Sample curled, swollen and } \\
\text { settled down, Solution a bit } \\
\text { cloudy }\end{array}$ & Bleeds yellow, and float \\
\hline 18. & $\begin{array}{lll}\text { Fragmentation } & \text { starts and } \\
\text { slight bleeding } & & \end{array}$ & $\begin{array}{l}\text { Urine colored solution, } \\
\text { Fragmentation complete }\end{array}$ & NOC \\
\hline 19. & $\begin{array}{l}\text { Sample curled and swollen, } \\
\text { Top layer gets separated }\end{array}$ & $\begin{array}{l}\text { Top layer fragmented while } \\
\text { other layers still intact, } \\
\text { Sample swollen and bleeds } \\
\text { light yellow }\end{array}$ & $\begin{array}{l}\text { Sample floats and starting } \\
\text { to get fragmented into } \\
\text { further very little pieces }\end{array}$ \\
\hline 20. & No visible changes & No visible changes & No visible changes \\
\hline
\end{tabular}

In Chloroform, almost all the samples floated on the first day but by the third day, they were settled down. Slight Curling and shrinking was seen on first day where as Bleeding happened rarely. On the second day most of the samples were curled and shrank completely. Bleeding occurred in few samples on the third day whereas most of the samples did not undergo any disastrous change from second to third day. Fragmentation also occurred rarely.

Table 3: Showing changes occurred in various samples when dissolved in Chloroform $\left(\mathrm{CHCl}_{3}\right)$

\begin{tabular}{|c|l|l|l|}
\hline Sample No. & \multicolumn{1}{|c|}{ Day 1 } & \multicolumn{1}{c|}{ Day 2 Day 3 } \\
\hline 1. & NVCC, Floating & Settled down & Complete shrinkage \\
\hline 2. & NVCC & Slight color change & NOC \\
\hline 3. & Floating & NVCC & NOC \\
\hline 4. & Curled, NOC & Floating & NOC \\
\hline 5. & NVCC, Floating & Curled Completely & Milky appearance \\
\hline 6. & NVCC, Floating & Curled slightly & Curled completely \\
\hline 7. & NVCC & NOC & NOC \\
\hline 8. & Slightly curled & NVCC & NOC \\
\hline 9. & Bleeding yellow & Floating & NOC \\
\hline 10. & NVCC & Sinking & Bleeding yellow \\
\hline 11. & Bleeding white, Floating & Complete shrinkage & Curled completely \\
\hline
\end{tabular}




\begin{tabular}{|l|l|l|l|}
\hline 12. & Slight color change, Floating & Slightly shrinked & Shrinkage, Bleeding yellow \\
\hline 13. & Floating & NVCC & NOC \\
\hline 14. & Slightly curled & Sinking & NOCC \\
\hline 15. & NVCC, Floating & NOC & NOC \\
\hline 16. & Shrinkage, Floating & Settled down & Slightly curled \\
\hline 17. & Slight Shrinkage, Floating & Complete shrinkage, settled down & NOC \\
\hline 18. & NVCC, Floating & Shrinkage & Milky appearance \\
\hline 19. & Slight bleeding, Floating & Curled, Fragmentation begins & Fragmentation completes \\
\hline 20. & NVCC, Floating, Slightly curled & Curled completed & NOC \\
\hline
\end{tabular}

The present study contrasts with a study performed by Cassissta and Sandercock in 1994 in which they used chemicals like Acetone, Toluene, Acetic acid etc to check whether the samples are soluble in these chemicals or not. The samples were not put for more than a few hours as Micro chemical Spot tests were performed. The result was that most of the samples were soluble in these chemicals.

Table 4: Showing results of UV spectrophotometry

\begin{tabular}{|c|c|c|}
\hline Sample No. & Wavelength & Absorption \\
\hline 5 & 267.55 & 0.894 \\
\hline 16 & 245.96 & 0.722 \\
\hline 17 & 271.25 & 0.988 \\
\hline 18 & 250.07 & 0.925 \\
\hline 20 & 254.99 & 0.993 \\
\hline
\end{tabular}

5 samples of automobile paint were analyzed under UV Spectrophotometry. All the samples show maximum absorption at wavelength $240-270 \mathrm{~nm}$. The maximum absorption of 0.993 at wavelength of $254.99 \mathrm{~nm}$ was seen by sample 20. Another sample named 17 also showed a maximum absorption of 0.988 at wavelength of $271.25 \mathrm{~nm}$. Almost all the samples showed good absorption peaks in the UV. This study can be a very good basis of forming a handbook which contains all the peaks generated by particular constituent in particular solvent.

The main techniques applied analysis of paint are generally FTIR, RAMAN spectroscopy, IR Spectroscopy, GC-MS and SEM-EDX. In most of the cases it has been seen that, a single technique has never been good at identifying all the elements present in a sample. A combination of 2-3 techniques is best if we want to identify and quantify nearly all the elements. This statement is supported by facts presented by Burke et al. (1985), Giang et al. (2002), Chen et al. (2014) and Kruglak et al. (2019).

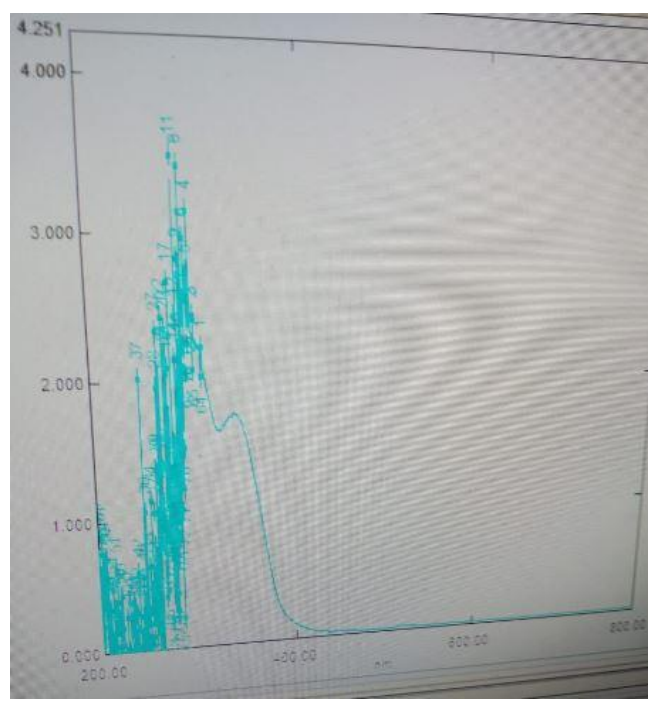

Fig. 1: Results of UV Spectrophotometry of sample 5

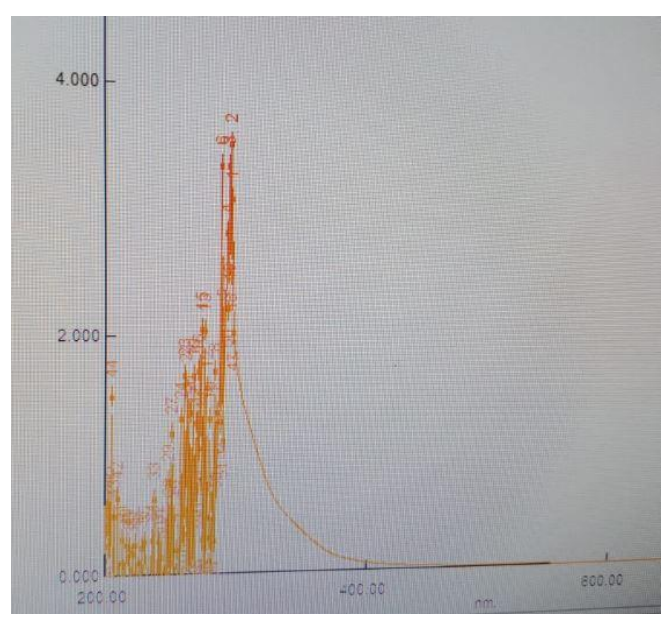

Fig. 2: Results of UV Spectrophotometry of sample 16 


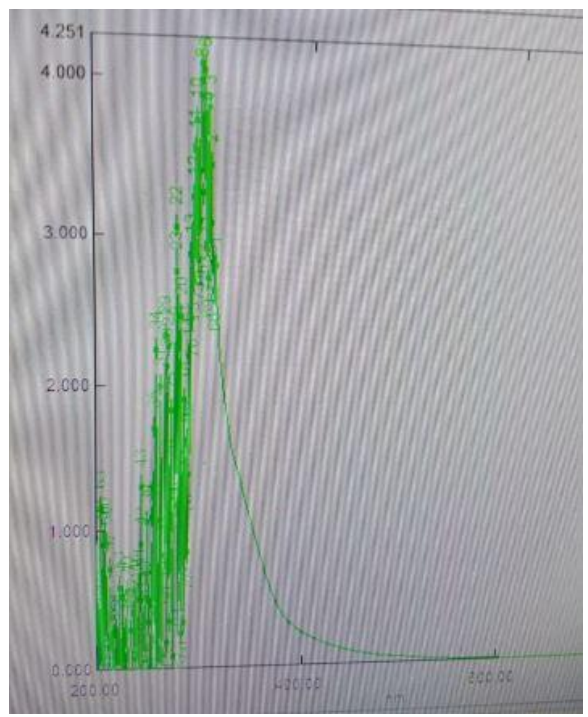

Fig. 3: Results of UV Spectrophotometry of sample 17

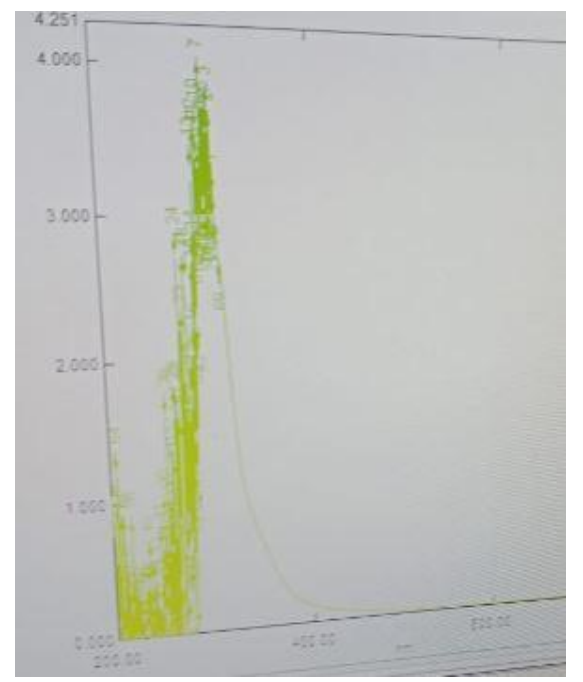

Fig 4: Results of UV Spectrophotometry of sample 18

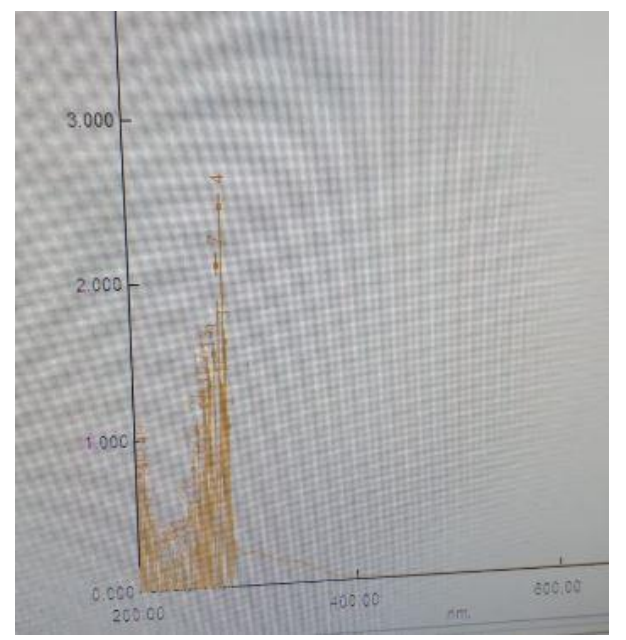

Fig 5: Results of UV Spectrophotometry of sample 20

\section{Conclusion}

Using solubility tests and instrumentation like UV-Vis Spectrophotometry, all the 20 samples were analyzed and differentiated. Solubility tests act as preliminary tests while instrumentation act as confirmatory test. Nearly all the samples were distinguished using chemicals like Sulphuric acid, Nitric acid and Chloroform. All the samples reacted differently to different chemicals while some reacted to Sulphuric acid very well; others show positive reaction in Nitric acid. UV Spectrophotometry was used to analyze 5 samples but due to unavailability of data, they were not able to get matched with reference. Through this research, a database has been created which can be useful in further forensic related work. It can be really helpful in hit and run cases where possibility of exchange of paint chips is very high.

\section{Source of Funding}

None.

\section{Conflict of Interest}

None.

\section{References}

1. Pfanstiehl J (1998). Automotive Paint Handbook: Paint Technology for Auto Enthusiasts \& Body Shop Professionals. Penguin. ISBN 978-1-55788-291-2

2. A Guide to Seals in the Automotive Industry, PreTreatment \& Paint Plants by A.R. Thomson group (https://arthomson.com/wpcontent/uploads/2013/04/Resources-MechanicalAESSEAL-Guides-AUTO.pdf)

3. A guide to auto paint colors by The coating store (https://www.thecoatingstore.com/car-paint-colors/)

4. A guide in Introduction to FTIR by Thermo Scientific. (http://tools.thermofisher.com/content/sfs/brochures/BR505 55_E_0513M_H_1.pdf)

5. Gothard, J., "Evaluation of Automobile Paint Flakes as Evidence," J Forensic Sci 1976;21(3):636-41,

6. Audette, R. and Percy, R., "A Novel Pyrolysis Technique for Micro Paint Analysis," J Forensic Sci 1978;23(4):6728.

7. Ryland, S. and Kopec, R., "The Evidential Value of Automobile Paint Chips," J Forensic Sci 1979;24(1):140-7.

8. Ryland, S., Kopec, R., and Somerville, P. "The Evidential Value of Automobile Paint. Part II: Frequency of Occurrence of Topcoat Colors," J Forensic Sci 1981;26(1):64-74 
9. Burke, P., Curry, C. J., Davies, L. M., \& Cousins, D. R. A comparison of pyrolysis mass spectrometry, pyrolysis gas chromatography and infra-red spectroscopy for the analysis of paint resins. Forensic Sci Int 1985;28(3-4):201-19.

10. Cassista, A. R., \& Sandercock, P. M. L. Comparison and Identification of Automotive Topcoats: Microchemical Spot Tests, Microspectrophotometry, Pyrolysis-Gas Chromatography, and Diamond Anvil Cell Ftir. Canadian Soc Forensic Sci J 1994;27(3), 209-23.

11. McDermott, S. and Willis, S. "A Survey of the Evidential Value of Paint Transfer Evidence," Journal of Forensic Sciences, 1997;42(6):1012-8.

12. Giang, Y., Wang, S., Cho, L., Yang, C., and Lu, C. "Identification of Tiny and Thin Smears of Automotive Paint Following a Traffic Accident," J Forensic Sci 2002;47(3):625-9.

13. Jose R. Almirall, Tatiana Trejos, Andria Hobbs, Kenneth G. Furton, "Trace elemental analysis of glass and paint samples of forensic interest by ICP-MS using laser ablation solid sample introduction," Proc. SPIE 5071, Sensors, and Command, Control, Communications, and Intelligence (C3I) Technologies for Homeland Defense and Law Enforcement II, (22 September 2003)

14. G. Edmondstone, J. Hellman, K. Legate, G.L. Vardy \& E. Lindsay. An Assessment of the Evidential Value of Automotive Paint Comparisons, Canadian Soc Forensic Sci J 2004;37(3):147-53

15. Flynn, K., O'Leary, R., Lennard, C., Roux, C., and Reedy, B. "Forensic Applications of Infrared Chemical Imaging: Multi-Layered Paint Chips," J Forensic Sci 2005;50(4):JFS2004502-10

16. Buzzini, P., Massonnet, G. and Monard Sermier, F, The micro Raman analysis of paint evidence in criminalistics: case studies. J Raman Spectrosc 200637:922-931

17. Troiano, N. W., Goldberg, C. G., Schlachter, P. B., \& Kacena, M. A. Paint Chip Analysis in a Forensic Investigation: Lessons Learned From Metal Bone Implants. J Histotechnology 2008;31(1):25-7
18. Szafarska, M., Woźniakiewicz, M., Pilch, M., Zięba-Palus, J., \& Kościelniak, P. Computer analysis of ATR-FTIR spectra of paint samples for forensic purposes. J Mol Struct 2009;924-926, 504-13.

19. Asfaw, A., Wibetoe, G., \& Beauchemin, D. Solid sampling electrothermal vaporization inductively coupled plasma optical emission spectrometry for discrimination of automotive paint samples in forensic analysis. J Anal Atomic Spectrom 2012;27(11):614-21.

20. Yang, S.-H., Shen, J. Y., Chang, M. S., \& Wu, G. J. Quantification of vehicle paint components containing polystyrene using pyrolysis-gas chromatography/mass spectrometry. Anal Methods 2012;4(7)

21. Rui Chen, Jungang Lv \& Jimin Feng () Characterization of Paint by Fourier-Transform Infrared Spectroscopy, Raman Microscopy, and Scanning Electron Microscopy-Energy Dispersive X-ray Spectroscopy, Anal Letters 2015;48:9:1502-10.

22. N. Zhang, C. Wang, Z. Sun, H. Mei, W. Huang, L. Xu et al, Characterization of Automotive Paint by Optical Coherence Tomography, Forensic Sci Int 2016.

23. Akafuah, N., Poozesh, S., Salaimeh, A., Patrick, G., Lawler, K., \& Saito, K et al. Evolution of the Automotive Body Coating Process-A Review. Coatings 2016;6(2):24.

24. K. B. Ferreira, A. G. G. Oliveira and J. A. Gomes, Raman spectroscopy of automotive paints: Forensic analysis of variability and spectral quality, Spectroscopy Letters 50;2(102)

25. Kruglak, K. J., Dubnicka, M., Kammrath, B., Maxwell, V., \& Reffner, J. A. The Evidentiary Significance of Automotive Paint from the Northeast: A Study of Red Paint. J Forensic Sci 2019.

How to cite this article: Verma $\mathrm{P}$, kaur M, Kaur N. Forensic analysis of automobile paint of Indian company. Int J Forensic Med Toxicol Sci 2019;4(3):7481. 